\title{
Stanisław Brzozowski’s performative criticism
}

\author{
Dorota Kozicka
}

Published online: 21 October 2011

(C) The Author(s) 2011. This article is published with open access at Springerlink.com

\begin{abstract}
Stanisław Brzozowski was active as philosopher and literary critic for only a few years at the turn of the twentieth century, yet his writings are still inspire contemporary thinkers and critics. In every important phase of the development of Polish literary criticism, Polish intellectuals have acknowledged Brzozowski as a writer who had the courage and critical acumen to confront modernity and examine closely contemporary trends of thought from the perspective of social and individual life. This continued presence of the celebrated critic cannot but be interesting for the researcher who is led to ask, what is so intriguing in Brzozowski's work, why do successive generations of critics and intellectuals return to Brzozowski? Drawing on many important interpretations of Brzozowski's work (Burek, Głowiński, Nycz), I want to show that in Brzozowski's work it is possible to find everything contemporary criticism and thought needs, because his books contain, in nuce, projects and strategies which can be (and are) used in different ways by critics representing different ideologies and worldviews. Brzozowski worked out, or rather attempted to work out, ideas which are a source of modern critical projects but in addition his work comprises a repertoire of possibilities which contemporary critical thought can turn to its advantage. Brzozowski's work can be also treated as a performative act, calling forth the reader's response, in this way shedding new light on it. I also show that "performative consciousness" is both close to Brzozowski's practice of writing and deeply rooted in his philosophical conviction. Brzozowski can be considered a representative of modernist, critical literature, in which reading and writing become a mode of experience, a privileged social discourse, and a "leaven," an act and an activity.
\end{abstract}

This essay is a fragment of a larger text, which was written for the project "Stanislaw BrzozowskiCo-repetitions. Genealogy of modernist literature and culture in Poland" (Nr N N103087637).

D. Kozicka ( $\square)$

Department of Polish Literature, Jagiellonian University, Gołębia 16, 31-007 Kraków, Poland e-mail: dorota.kozicka@uj.edu.pl 
Keywords Criticism $\cdot$ Brzozowski $\cdot$ Modernity $\cdot$ Performativity $\cdot$ Literary criticism

My mind is in a process of continuous creation and I think that I will be able to do things which will leave behind what I have been able to write thus far (Brzozowski and Listy 1970a).

Stanisław Brzozowski and Karol Irzykowski are the two high points of Polish modernist literary criticism, although, we must add immediately, for completely different reasons.

Brzozowski's work, unfinished, radical and full of polemical zeal, became in a particular way a point of reference for many Polish writers, literary critics, and intellectuals throughout the twentieth century and to the present day. Many literary critics have made more or less well-grounded references or allusions to Brzozowski's opus. Some amount to superficial sloganeering due not so much to a profound knowledge of Brzozowski's writings, but to his very high position on the Polish intellectual scene, and which amount to gestures of approval or refutation. On the other hand, it is impossible to understand the literary works of such writers as Bogdan Suchodolski, Ludwik Fryde, Kazimierz Wyka, Czesław Miłosz, Tomasz Burek, Andrzej Werner, or Cezary Michalski without considerable knowledge of Brzozowski's works (and biography).

In every important phase of the development of the Polish literary criticism, Polish intellectuals have acknowledged Brzozowski as a writer who had the courage and critical acumen to confront modernity and examine closely contemporary trends of thought from the perspective of social and individual life. Still, some doubt whether Brzozowski's writings have been satisfactorily analyzed and whether his ideas have been approached with sufficient critical distance by successive generations of his interpreters who have not always displayed sufficient critical force and intellectual passion.

There is no room here for a detailed analysis of contemporary Polish literary criticism; it is enough to say that Brzozowski-whose work was from the beginning an inspiration for totally different ideologies - is considered a spiritual patron of both the radical Polish intelligentsia as well as the Polish nationalist right movement. In the years 1918-1939 he inspired personalist criticism as well as Czesław Miłosz, ${ }^{1}$ and during the Second World War a group of young writers gathered round the patriotic and nationalist periodical "Sztuka i Naród." During the exceedingly important period in Poland of October 1956, Brzozowski became the patron not only of the revisionists (Tomasz Burek), or the personalists (Jan Błoński), but equally of the younger structuralists (including the initial pronouncements of Slawinski and Glowinski). He also played an important role at the beginning of

\footnotetext{
${ }_{1}$ Miłosz read Brzozowski abundantly during the thirties, and he often repeated that the influence Marxism had on him and many other young intellectuals at that time was a result of Brzozowski's impact on them. Miłosz wrote his famous, early polemical text, Bulion $z$ gwożdzi, under the influence of Brzozowski's style of writing. It is also worth noticing that Miłosz wrote a book about Brzozowski, entitled Człowiek wśród skorpionów.
} 
seventies, when the representatives of the Nowa Fala [New Wave] generation wrote their zealous manifestos.

Brzozowski's "presence" has also been significant in recent years among both rightist (Teologia polityczna) and leftist (Krytyka Polityczna) circles; what is especially interesting from my point of view is that Polish postmodern literary critics find in Brzozowski support for their idea that a critic should challenge current [popular] and well-established opinions.

This continued presence of the celebrated critic cannot but be interesting for the researcher who is led to ask, what is so intriguing in Brzozowski's work, why do successive generations of critics and intellectuals, representing very different worldviews and strategies, return to Brzozowski to find, as they declare, “... under the covers of the anachronistic language of Young Poland vital thinking and essential reflections touching on themes engaging them here and now?"2

One of the reasons for Brzozowski's influence is doubtless the scope of his production, ranging over literary criticism and literature, philosophy, as well as social and political journalism. All those genres form a large-scale project (or, strictly speaking, projects) of a philosophy of culture, which is deeply rooted in the analyses of the literature, philosophy, and criticism of Brzozowski's time.

Another probable reason for Brzozowski's influence is the unusual emotional tension characteristic of his writings which affected both his contemporaries, who read Brzozowski's articles in periodicals in the context of heated polemics and vehement declarations, and successive generations of readers.

Finally, in my opinion, Brzozowski's work was and still is influential because one can find anything one wants in it. This statement seems ambiguous-at once compromising and praising-since on the one hand it attests to the fact that Brzozowski lacked a definite worldview and program, that he wrote chaotically and ambivalently, changing his views, and even contradicting himself. ${ }^{3}$ But on the other hand, as Tomasz Burek, Michał Głowiński, and Ryszard $\mathrm{Nycz}^{4}$ have shown, Brzozowski's style of writing may bear witness to the fact that he understood the role and the essence of criticism in a very special way. Nycz, for example, demonstrated convincingly that in Brzozowski's case the chaotic diversity of his critical interests and stylistic variety are neither the "fruit of an uncontrolled eruption of readerly divagations" nor "testimony to the evolution of his thinking," but can be treated as the "non-linear growth of persistent attempts to work out the thought about a single problem" (Nycz 1997, pp. 120-121)..$^{5}$ The "labouring out" of the problem and the attempts to transmit the results consist in looking for ever newer philosophical languages, new concepts, new opinions, and new readings. Drawing on Nycz's interpretation, it needs to be added, then, that in Brzozowski's

\footnotetext{
2 The "Krytyka Polityczna" circle considers Brzozowski its patron. Cf. http://www.krytykapolityczna.pl/.

3 A survey of such opinions is to be found in the introduction to Brzozowski's letters. See Sroka (1970). Brzozowski's Legenda Mtodej Polski was both praised and criticized for the very same statement, which is proof that his texts can be interpreted in very different ways. Cf. Głowiński (1997), A. Mencwel (2001).

4 Burek (1973), Głowiński (1997), Nycz (1997).

5 According to Nycz, Brzozowski wanted to explain "yet again the same key picture and the same basic experience" (the idea that reality is dynamic and changing).
} 
work it is possible to find everything modern criticism and modern thought needs, because his books contain, in nuce, projects and strategies which can be (and are) used in different ways by critics representing different ideologies and worldviews. ${ }^{6}$ Brzozowski's modernity consisted then not only in the fact that he worked out, or rather attempted to work out, ideas which are a source of modern critical projects (which is in fact the case), but also in the fact that his meandering, open, incessantly reconstructed work, feeding on ever newer influences (connected within a larger perspective on the course of his life) comprises a repertoire of possibilities which contemporary critical thought can turn to its advantage. ${ }^{7}$ Brzozowski worked out his views anew, as well as the language adapted to expressing and implementing them, in each and every act of his critical reading and writing.

Such an interpretation of Brzozowski's work, along the lines of the earlier accounts by Głowinski and Nycz, is today hardly new. Nevertheless, with recourse to the analytical tools worked out by the representatives of the so called performative turn, ${ }^{8}$ we can treat Brzozowski's work as a performative act, as action which is self-referential and which, at same time, constructs reality, calling forth the reader's response, in this way shedding new light on it. ${ }^{9}$

The "performative consciousness" treats literature/the utterance as an act or event, a treatment that is both close to Brzozowski's practice of writing and deeply rooted in his philosophical conviction. ${ }^{10}$ Idee [Ideas] is a remarkable example of the fusion of thought and writerly practice, an attempt not only to build a new intellectual order but to construct a new and more appropriate textual expression for it as well. However, this feature is also present in all three books Brzozowski wrote in his last years: not only in Idee, but in Legenda Mtodej Polski, Głosy wsród nocy, as well as Pamiętnik. What's more, this way of thinking and writing can likewise be

\footnotetext{
${ }^{6}$ It is worth noticing that the opinions and ideas Brzozowski sketched, which now (meaning: with retrospect in light of his later development) may seem contradictory were not perceived as such in his day.

7 This repertoire of possibilities can also be described in Bourdieu's terms, who pictured Baudelaire as a lawgiver to the literary field at the stage when it was acquiring autonomy. Cf. Bourdieu (2001) pp. 96-108.

8 The term 'performative turn' refers here not to the spectacular changes in the arts in the sixties, but to the changes in philosophy and theory of culture during the nineties. They helped to refashion the dominant interpretation of culture as text shifting instead to its performative qualities. From this perspective, performative utterances are rhetorical devices, speech acts which do not simply imitate reality but organize it, bringing things into being. Cf. Wirth (2002), Fischer-Lichte (2004), Loxley (2007), Zeidler-Janiszewska (2007).

9 It is not my purpose to apply specific theories of performativity to Brzozowski' work. I am looking for some general intellectual similarities, inspirations, and sources of performative thinking in the broad modernist tradition, which was codified in Poland by Brzozowski.

10 Ryszard Nycz emphasized this connection in his essay "Wywoływanie świata." He described the basic features of Brzozowski's philosophical project (a turn from substantial to functionalist thinking, rejection of the subject-object opposition, and the process-work opposition,) which are the basis for his philosophy of culture, for his theory of language as a means of social communication, and for his vision of literary criticism, as well. Nycz concludes by remarking that for Brzozowski "everything becomes, in a sense, discourse," and the purpose of his criticism was to study "the logic of both creation and, at the same time, recreation (poetics and the rhetoric of culture)," while I want to emphasize the performative aspect of Brzozowski's writings. Cf. Nycz (1997), pp. 131 and 134-135.
} 
found in Brzozowski' earliest texts. ${ }^{11}$ In the article Miriam, published in 1904, and which is one of his most important literary manifestos, the critic wrote:

We must finally finish with the myth of unconditional truth existing outside of us, determined once and for all. The act $[c z y n]$ is the only form through which we can have direct knowledge of reality, being then cannot be something that the act posits and at the same time excludes its possibility. We should not say that the world is, but that it is becoming, and freedom is the last word in the solution of the mystery of being. Being will be what it makes itself to be, what we will make of it: hence it is freedom [Brzozowski 1973, 82].

The breakthrough in philosophy I am talking about consists in the fact that freedom is taking the place reserved till now for finite and determined being. There is no being as such. Free creation is the essence of the world. Action and creation are not an illusion but the highest truth, and humanity has been maturing to understand and glimpse this truth [Brzozowski 1973, 88-89].

Examining the consequences of Brzozowski's so called philosophy of action [filozofia czynu] and its successive stages, and suspending Fichte's influence on its early phase, we can interpret it as a whole as a specific performative act.

Brzozowski recast and re-wrote in a number of different ways the idea that being is not a stable category, given once and for all, and that thought does not describe a reality which is independent and prior to intellectual creativity, but rather calls reality into existence. He tried to convince his readers that "the basic originary element of the world is value, active construction, and not the fact. Not closed, finite, and dead being, but action is the essence of the world," and "art does not imitate the stream of life but it creates life" (Brzozowski 1973, 93). As a consequence of these epistemological theses, the role and task of literary criticism are seen as an act which co-creates and co-constitutes the meaning of a literary work. In Miriam Brzozowski also wrote:

Science is not able to seize a work of art directly. To be understood a work of art must be recreated, created anew. Every kind of critical activity arises from a creative act which constitutes its object and attributes significance to it. (Brzozowski 1973, 81)

\footnotetext{
11 Brzozowski's essay Scherz, Ironie und tiefere Bedeutung can be considered the first both successful and unsuccessful attempt at a "performative critical act," similar to a real performance, where it is impossible to ascertain unambiguously whether the intervention of the audience is successful or not. Brzozowski wrote this essay, in which the main character is a porcelain figurine of Miriam, in the form of a dream. Readers and critics understood this text as a satire and pamphlet only, and Brzozowski felt obliged to present his polemical stance in a traditional way, by giving it the form of traditional and rationally constructed arguments. As a response to critical opinions, Brzozowski wrote: "For a year already I have been ridiculing and fighting in diverse ways against Miriam, this taboo of Polish artists. For a year already I have been writing this article in a variety of ways, which the seven, who signed this protest, have read only now. I do not care if my concepts will be considered earthbound so long as they bring about what I intended: they interrupted the peaceful slumber of those whom I wanted to wake" (Gtos 1904, nr 34). The essays, in which Brzozowski launched a "serious" polemic against Miriam, were published in the subsequent volumes of Gtos in the same year (see: Miriam, in: S. Brzozowski, Kultura $i$ zycie (Brzozowski 1973 pp. 73-102).
} 


\section{II}

Considering literary criticism from the currently acknowledged and fruitful performative perspective is justified by its very character as activity, in particular if it is treated as a form of intellectual activity setting out specific beliefs, but also displaying the potential hidden in an act/event of reading and interpretation. On the one hand, this performativity can be connected to the dramatic character of a critical act; it is enough to recall the inherent similarity between a critical utterance ("which can be directed to a single partner, but is at the same time directed to another") and an utterance of a character in a drama ("which solicits not only the other characters on stage, but the audience, too") (Sławiński 1998, 166). On the other hand, according to the partisans of contemporary engaged criticism, the performative dimension of criticism consists in the fact that in carrying out an action on texts (both those which the critic reads and which he writes) the critic at the same time reconfigures/changes/transforms the state of affairs obtaining in the field of literature, criticism, culture, and social reality. ${ }^{12}$

From the very beginning of his critical activity Brzozowski shared the idea that criticism can and should change both social consciousness and social reality (today we could call this idea a performative consciousness). This is demonstrated by the very important role he ascribed to criticism in social life, by the fervor with which he expressed his opinions, his aggressive polemics together with the dignified tone of his interventions, the many points of view he espoused, as well as the by the open character of his discourse, the way in which he composed his declarations (as a set of many, often contradictory statements and as a combination of critical reflection and dramatized dialogues, scenes), ${ }^{13}$ or finally by the importance he gave to the epistemological and rhetorical aspects of language. ${ }^{14}$ One of the best testimonies to this effect are his oft-repeated attempts to clarify his own practices as well as the essence of critical practice in general. An important statement is to be found in a letter to the Szalits dated January 1911:

A critic cannot give You your picture of an author, he cannot give You anything You could compare with works... A critic always offers a dramatized collision of his own soul with the problems of high culture. His writings are new things and must be new things. They are in and for themselves. Criticism is sufficient unto itself, or it suffices for nothing (Brzozowski and Listy 1970b, 532).

And Brzozowski added: "[Criticism] is my form of philosophy, as the dialog is for Plato"; "... all of it seems to be a volume of essays, but in fact it is my own dramatized autobiography." (ibid.).

\footnotetext{
12 I am refering to Igor Stokfiszewski's manifestos, a critic representing the "Krytyka Polityczna" circle.

13 Burek (1973) described a principle of "dramatic presentation” found mostly in Brzozowski's novels. Głowiński (1997) analyzed the open character of Brzozowski's discourse, focusing on two important rules, which he called, respectively, "a great parataxis" and "foreground." Both rules enable building a dynamic discourse by the addition of successive arguments.

14 Brzozowski's linguistic experience is analyzed by Nycz in his Nycz (1997) essay.
} 
Worth emphasizing in these self-commentaries by Brzozowski is the selfreferential (self-sufficient) and personal character (shown as the dramatized collision of the self and the world) of the critical act. This collision with the world (culture), which in many of his texts is shown as dynamic, dramatic, and theatrical, is a source of creativity allowing criticism to create new things and new meanings, constructing reality, not only commenting it and imitating ["picturing"] it.

This untiable knot of life and writing may also be responsible for the totalizing character of Brzozowski's work, the many-sided creativity and multidimensionality of his activities. What $\mathrm{I}$ have in mind here is that he practiced simultaneously not only social journalism, literary and theatre criticism as well as literature, but also aesthetics and philosophy, or rather, more exactly, a philosophy of culture in a broad sense of the term ${ }^{15}$; his countless readings likewise influenced not only his many projects but his life decisions as well. Brzozowski's concept of criticism as a "dramatized autobiography" resulted not only in the diversity and changeability of his interests, but also in very high expectations placed on his reader, and, consequently, in the enormous persuasive, communicative, and performative impetus of his texts. In the opening article of Głosy wśród nocy, entitled "Kilka uwagach o stanie ogólnym literatury europejskiej" [Some remarks about the overall state of European literature] Brzozowski writes:

In general, I would like my reader to understand that my books are a system of appeals and intellectual impulses, and that they do not have any established meaning which it would be vain to seek. My task is to surprise my reader and situate him in such a way that, were he to want to be in harmony with life and himself, he would find in my books more or less the ideas I wanted to convey. A reader who from the start does not want to grant, not the book but himself the least vital and personal energy would do better not to read these things. There are books written in such a way as to enable Polish children, grown gray and balding, but still obedient, to learn without any effort (Brzozowski 2007a, $51)$.

The passage is a good example of how Brzozowski managed to reconcile his philosophical views with his textual practice, and it illustrates his conviction that there does not exist a ready-given, closed, and finite text or meaning, and, therefore, that in our existential 'here and now' it is necessary constantly to refashion our worldview and the concepts serving to define it.

This project of reading his own texts resulted undoubtedly from Brzozowski's experience of treating reading not as an adventure but as a task, as an inseparable element of criticism in which the other's speech becomes, metaphorically speaking, the leaven of new thinking.

\footnotetext{
15 According to A. Mencwel, "irrespective of what Brzozowski writes about he remains a social thinker, a philosopher, a theoretician of science, and a literary and art critic, at the same time. Every thematic 'classification' of his writing is then to some extent artificial." In the introduction to Brzozowski's early critical writings entitled "Między 'nową sztuka' a 'społecznym ideałem," Mencwel (1988) describes the total critical stance, characteristic for Brzozowski.
} 


\section{III}

The type and effects of Brzozowski's fervent readings attracted interest from the very beginning of research on his writings. It is enough to recall Ostap-Ortwin's picturesque definition from his preface to Głosy wsród nocy, according to which Brzozowski's studies on English literature were for him a "leaven of crucial solstices in the process of accelerated intellectual fermentation" (Brzozowski 2007a, 27), or his remarks that, according to Brzozowski, people and works, books and their authors were, from the beginning, a field of trials and experiments to check out certain methods and postulates (...)"(ibid, 41). Brzozowski himself, aware of the "experimental" and innovative character of his criticism and pre-textual treatment of other authors' texts, wrote in a letter concerning the genesis of Gtosy wśród nocy: "Browning, Meredith, Emerson will give me a chance to say many interesting things about the most up to date frames of mind and creativity." (ibid. $32)$.

The history of the emergence of Gtosy wsród nocy, documented in Brzozowski's own letters and Ostap-Ortwin's recollections, demonstrates exceedingly well the incessant movement of Brzozowski's thought, the influence of his intense reading on subsequent projects for his own book, and how he reworked in ever new ways and with the help of the other writers the questions on his mind. A spectacular example of this remodeling are the two versions of the extensive introduction Brzozowski wrote to Głosy wśród nocy. Entitled, respectively, Kilka uwag o stanie ogólnym literatury europejskiej i o zadaniach krytyki literackiej I and Kilka uwag o stanie ogolnym literatury europejskiej i o zadaniach krytyki literackiej II, they are two independent texts each presenting the key questions of the entire book in a completely different way and, as the publisher emphasized, “... from a different perspective and in a different light," rather than being two versions of the same text differing only by virtue of the author's point of view. ${ }^{16}$ Another example of this kind of reworking are numerous meta-critical remarks present in these texts, ranging from metaphors to the large narratives about the critic and the dynamic definitions of his duties and activities. The lack of an overarching metaphor, tenacious testing of many metaphors (for example, the critic as paleontologist, cartographer, the ever watchful guard), the preponderance of verbs describing action over terms illustrating the critic's features increase the ambiguity and "shifting character" of Brzozowski's writing, and indicate a constantly repeated act of creating values, an act which is close to a performative act.

Brzozowski's critical work consisted in a continuous repetition of an act of critical reading and on its basis adding subsequent affirmations which were an active record of his meditations and critical revisions of his own views. At the same time, they were directives for a reader of his notes to perform the same intellectual work. In this performative gesture, repetition of a reading-writing act ties in with the elaboration of the subsequent variants of philosophical reflection on culture. Brzozowski's idea of the act of reading seems to correspond to that of Roland

\footnotetext{
16 See Ostap-Ortwin's footnote to Kilka uwag o stanie ogólnym literatury europejskiej $i$ o zadaniach krytyki literackiej II. (Brzozowski 2007a, 109).
} 
Barthes (especially to those of his views considered to be his contribution to the socalled performative turn). According to Barthes, there is a constitutive connection between reading, writing, and criticism, and a text is but a process of generating meanings. According to Barthes, an act of reading is open to "a labour of infinite codes" and the "multiplicity of the Text" (Barthes 1999, 44-47) during which a reader "... does not decipher, but creates, shuffles languages, letting them overlap indefinitely: he himself is this overlapping." (Barthes 1995, 383 following Markowski 1999, 30). ${ }^{17}$ Understood in this way an act of reading and simultaneously critical thought evince a creative, spiritual, and intellectual (even a somatic, if we take into consideration Brzozowski's illness and its influence on his writings) character. Reading of this kind helps to undermine worn, no longer serviceable notions making it the case that, as Brzozowski put it in Głosy wśród nocy, "... a critic is a profound creator" (Brzozowski 2007a, 49).

All this allows us to conclude that Brzozowski can be considered a representative of modernist, critical literature, in which reading and writing become a mode of experience, a privileged social discourse, and a "leaven," an act and an activity. As Brzozowski wrote, "... a critic must give birth to the earth ...," he must "build the country, the climate, and the earth for creatures who do not so much exist as foresee their future possible natures." (ibid).

Open Access This article is distributed under the terms of the Creative Commons Attribution Noncommercial License which permits any noncommercial use, distribution, and reproduction in any medium, provided the original author(s) and source are credited.

\section{References}

Barthes, R. (1995). In E. Marty (Ed.), Ouevres complètes, vol. 3. 1974-1980. Paris: Ediions du Seuil. Barthes, R. (1999). S/Z (M. P. Markowski, M. Gołębiewska, Trans.). Warszawa: Wydawnictwo KR.

Bourdieu, P. (2001). Reguty sztuki. Geneza i struktura pola literackiego. (A. Zawadzki, Trans.), Kraków 2001, pp. 96-108 (Les règles de l'art. Genèse et structure du champ littéraire).

Brzozowski, S. (1973). Kultura $i$ życie. Zagadnienia sztuki i twórczości. W walce o światopoglad. (M. Sroka, Ed.). Warszawa: Państwowy Instytut Wydawniczy.

Brzozowski, S. (1990). Idee. Wstęp do filozofii dojrzatości dziejowej. (S. Góra, \& M. Sroka Eds.). Kraków: Wydawnictwo Literackie.

Brzozowski, S. (1998). Wczesne prace krytyczne. (M. Sroka Ed.). Warszawa: Państwowy Instytut Wydawniczy.

Brzozowski, S. (2007a). Gtosy wśród nocy. Studia nad przesileniem romantycznym kultury europejskiej. (Ortwin O. Ed.). Warszawa: Wydawnictwo Krytyki Politycznej.

Brzozowski, S. (2007b). Pamiętnik. (M. Wyka \& M. Urbanowski Eds.). Wrocław: Ossolineum.

Brzozowski, S. Listy (1970a). (M. Sroka Ed.). T. I. Kraków: Wydawnictwo Literackie.

Brzozowski, S. Listy (1970b). (M. Sroka Ed.). T. II. Kraków: Wydawnictwo Literackie.

Brzozowski, S. [response] In: Głos 1904 nr 34.

Burek, T. (1973). Arcydzieto niedokończone. In T. Burek, Dalej aktualne (pp. 40-95). Warszawa: Czytelnik.

Fischer-Lichte, E. (2004). Ästhetik des Performativen. Frankfurt/Main: Suhrkamp.

\footnotetext{
17 Brzozowski and Barthes assigned completely different functions to the act of reading. For the first it is a matter of responsibility, for the second one of pleasure. Some similarities can be found in their views about the essence of critical thinking and the role of "other voices" in shaping a critic's consciousness.
} 
Głowiński, M. (1997). Wielka parataksa. O budowie dyskursu w legendzie Młodej Polski Stanisława Brzozowskiego. In M. Głowiński (Ed.), Ekspresja $i$ empatia. Studia o mtodopolskiej krytyce literackiej (pp. 265-305). Kraków: Wydawnictwo Literackie.

Loxley, J. (2007). Performativity. London and New York: Routledge.

Markowski, M. P. (1999). Ciało, które czyta, ciato, które pisze. In R. Barthes (Ed.) S/Z. (M. P. Markowski, M. Gołębiewska Trans.) (pp 5-34). Warszawa: Wydawnictwo KR.

Mencwel, A. (1976). Stanistaw Brzozowski. Ksztattowanie mysii krytycznej. Warszawa: Czytelnik.

Mencwel, A. (1988). Między nową sztuką a społecznym ideałem. Krytyczna młodość Brzozowskiego. In S. Brzozowski \& M. Sroka (Eds.), Wczesne prace krytyczne (pp. 5-51). Warszawa: Państwowy Instytut Wydawniczy.

Mencwel, A. (2001). No! Io non sono morto... Jak czytać legende Młodej Polski? Kraków: Wydawnictwo Literackie.

Miłosz, C. (1982). Człowiek wsród skorpionów. Studium o Stanistawie Brzozowskim. Warszawa: Państwowy Instytut Wydawniczy.

Miłosz, C. (1996). Legendy nowoczesnosíi. Eseje okupacyjne. Listy-eseje Jerzego Andrzejewskiego $i$ Czestawa Miłosza. Kraków: Wydawnictwo Literackie.

Nycz, R. (1997). Wywoływanie świata. Zadania krytyki i sztuki w pisarstwie filozoficznym Stanisława Brzozowskiego. In R. Nycz (Ed.), Język modernizmu (pp. 119-154). Wrocław: Monografie Fundacji na Rzecz Nauki Polskiej.

Sławiński, J. (1998). Funkcje krytyki literackiej. In J. Sławiński (Ed.), Dzieło, język, tradycja. Prace wybrane. T.II (pp. 159-183). Kraków: Universitas.

Sroka, M. (1970). Legendy Brzozowskiego. In S. Brzozowski, Listy, M. Sroka (Eds.). (pp. VII-LXXX). Kraków: Wydawnictwo Literackie.

Wirth, U. (Hg) (2002). Performanz. Zwischen Sprachwissenschaft und Kulturwissenschaften. Frankfurt/ Main: Suhrkamp Wissenschaft.

Zeidler-Janiszewska, A. (2007). Perspektywy performatywizmu.Teksty Drugie nr 5 (pp. 34-47). 